\title{
Om bidragyderne
}

Gunhild Agger, lektor i dansk ved Aalborg Universitet. Har skrevet om litteraturteori, litteratur- og mediehistorie, populærkultur, reklamer, TVfiktion m.m. Perioderedaktør i projektet 'Dansk Medichistorie'.

Michael Bruun Andersen, mag. art. i filmvidenskab (KU), førsteamanuensis ved Institutt for medier og kommunikasjon, Universitetet i Oslo. Har senest redigeret Media and Democracy (1996) og publiceret TV-Nyheter $i$ Norge. En sammenligning mellem 2 kanaler (1996).

Ove Christensen, cand.mag. i idéhistorie og samfundsfag (ÅU/AAU), adjunkt i dansk ved Aalborg Universitet. Har redigeret bøger om kritisk teori og fortolkningsteori og udgivet en række artikler om kulturanalyse, film og TV.

Jens F. Jensen, lektor i dansk/medievidenskab ved Aalborg Universitet. Har redigeret Analyser af TV og TV-kultur (1991) og The Computer as a Medium (sammen med P. Bøgh Andersen \& B. Holmqvist) (1993); og har senest udgivet Teknologi-semiotik. To essays om teknologi, tegn og betydning (1994) og Multimedier og teknologiudvikling (1995).

Peter Larsen, professor ved Institutt for Medievitenskap, Universitetet i Bergen. Har udgivet artikler og bøger, der historisk, teoretisk og analytisk behandler massekulturens forskellige former, specielt sådan som de formidles gennem de moderne billedmedier, film, TV. Udgav i 1989 Tidens Tegn og i 1991 Det private Øje. Essay om Billeder og Blikke.

Preben Raunsbjerg, cand.phil. i dansk (AAU), ph.d.-studerende ved Aalborg Universitet i et projekt om TV-sport. Har bl.a. skrevet om TVreklamer i $K \& K$ 74.

Jørgen Stigel, lektor i kommunikation ved Aalborg Universitet. Har redigeret Mediehåndbogen (sammen med F. Mortensen og J. Poulsen) (1990) og Reklame - Kultur (sammen med J. F. Jensen og T. A. Rasmussen) (1993), publiceret en række artikler om reklame, TV og æstetik og senest udgivet Reklamen i dansk landsdcekkende TV (sammen med Christian Jantzen) (1995). 